\title{
When the Blind Lead the Blind: the Fallacy of Promoting Standard British English Accent in Cameroon
}

\author{
Aloysius Ngefac* \\ Department of English and American Studies, University of Regensburg, 93040 Regensburg, Germany \\ Email: angefac@yahoo.co.uk
}

\begin{abstract}
The paper argues, with reference to different empirical studies, that the promotion of Standard British English accent in Cameroon to the detriment of educated Cameroon English pronunciation is an unrealistic goal. The argument is based on the fact that Cameroon displays unique sociolinguistic and pragmatic realities that make the promotion of Standard British accent an unattainable goal.
\end{abstract}

Index Terms-Cameroon, ELT, standard British English accent, Cameroon English accent, contextual realities

\section{INTRODUCTION}

In spite of the fact that many research works (see, for instance, Masanga 1983; Mbangwana 1987; Bobda 1994; Anchimbe 2006 and Ngefac 2008) have clearly demonstrated that the English language in postcolonial multilingual Cameroon has undergone significant indigenisation and, consequently, nativisation, Standard British English (SBE) accent continues to be the preferred pronunciation model in the ELT industry in Cameroon. Interestingly, in most English Language textbooks used for the teaching of the language, drills on SBE accent abound and no drills are provided for educated Cameroon English (CamE) pronunciation. In fact, in all examinations that involve the testing of pronunciation (e.g. the entrance examination into the Higher Teacher Training College Yaounde), RP or SBE accent is always the target. Apart from Ngefac (2008 b), RP or SBE is always the reference accent in most research works (e.g. dissertations, theses and scientific papers, such as Bobda 1991) carried out on phonology in Cameroon. In other words, informants are always evaluated in most of these research works in terms of their knowledge of RP, and not in terms of their knowledge of educated CamE. The purpose of this paper is therefore to demonstrate, with reference to some empirical studies, that SBE is a far-fetched phenomenon in Cameroon, in spite of official efforts to promote it and in spite of some speakers' qualification of their accent as SBE.

\section{THE STUdy OF CAMEROON ENGLISH WITHIN THE WORLD ENGLISHES FRAMEWORK}

The English language that was at one point the language of a few countries is now a global language. In the different new nations where the language has been transplanted, it has evolved according to the ecological, cultural and sociolinguistic realities of such contexts (Kachru 1986; Graddol 1997; Mufwene 2001; Anchimbe 2006; Schneider 2007 ; and Ngefac 2008a). Kachru's $(1985,1986)$ three concentric model "helps promote varieties of English by drawing attention to their systematicity, robustness, creativity, communicative potential and relative prestige" (Rajadurai, 2005:4). In these new nations, the structure of the language at all linguistic levels is significantly influenced by contextual realities and the language tends to display significant differences from British English and other traditional native Englishes.

As a result of the nativisation of the English language in the new nations, each of the countries where a new English is spoken is now claiming its own standard of the language. One can now identify in the literature expressions such as Indian Standard English and Nigerian Standard English. This trend towards recognizing the New Englishes spoken in the new nations is in conformity with Kachru's (1992:11) recommendation that "it is indeed essential to recognise that World Englishes represent certain linguistic, cultural and pragmatic realities and pluralism, and that pluralism is now an integral part of World Englishes and literatures written in Englishes". In spite of Kachru's recommendation and the efforts made by scholars from different parts of the world to defend the status, acceptability and equality of Englishes in the three concentric circles, some Outer Circle speakers continue to think that traditional native English norms are superior to those of their indigenised English, despite the positive attitude they show towards their local English. Rajadurai (2005:6) captures this tendency in the following words:

[Outer Circle] speakers express pride in their own accents and varieties, and yet at the same time, espouse a preference and yearning for the native-speaker accent and for traditional old variety norms.

\footnotetext{
* Aloysius Ngefac teaches at the University of Yaounde I and is currently residing at the University of Regensburg as a fellow of Alexander von Humboldt Foundation.
} 
In postcolonial Cameroon, it is interesting to report that many Cameroonians now show a positive attitude towards their variety of English, in spite of official efforts to implant a traditional native English accent in Cameroon. In a previous investigation (see Ngefac 2009), up to $32 \%$ of my informants expressed a preference for CamE. In spite of this positive attitude towards CamE, there is still the strong belief that Western models of English, such as RP or SBE, should be the target of anybody who wishes to speak good English and hopes to have more professional opportunities. Bobda (2002: v) expressed this view in the following words:

While acknowledging the legitimate emergence of an autonomous variety of English in Cameroon, I believe that we are still, in many ways, dependent upon British and American norms. Our educational and professional successes are still dependent on these norms.

If ELT goals in Cameroon are aimed at promoting SBE accent, the fundamental task we have at hand is to evaluate the extent to which such a variety of English has actually been implanted in Cameroon, given, especially, the multilingual and other realities that sanction the teaching and learning of English in Cameroon.

Unlike most Western contexts, Cameroon displays a complex multilingual landscape. Besides French and English as the country's official languages, there are approximately 280 indigenous languages. In addition, there is Cameroon Pidgin or what is currently referred to as Kamtok, a lingua franca that is spoken by many Cameroonians of all walks of life, irrespective of their linguistic background, level of education, tribe, gender, age and occupation. Besides, there is Camfranglais, a language whose linguistic items are drawn mostly from English, French, Kantok and Cameroonian indigenous languages. It is spoken mostly by the younger generation (see Kouega 2003a and b). In addition, these languages spoken in Cameroon, such as French, English and Pidgin English, also have their respective varieties that are determined by such factors as education, region, gender, age, tribe and occupation (see Ngefac 2008a). In such a complex linguistic landscape where more than 280 languages and the different varieties of some of the languages are spoken in the same country, coupled with other sociocultural and pragmatic realities, can the promotion of SBE accent yield the expected results?

\section{ON ENGLiSH LANGUAGE TEACHERS' SELF-ASSESSMENT OF THEIR ENGLISH}

Questionnaires were administered to English Language teachers to make an assessment of their own English, by choosing from the options provided in the questionnaire which variety of English they speak and use as a medium of instruction. The following table captures the results obtained from the analysis of the responses of the 30 informants who made up the sample.

TABLE 1

SELF-ASSESSMENT TEST INVOLVING ENGLISH LANGUAGE TEACHERS IN CAMEROON

\begin{tabular}{|l|l|}
\hline Variety & Percentage \\
\hline British English (BrE) & 33.3 \\
\hline Cameroon English (CamE) & 23.3 \\
\hline A mixture of BrE, AmE and CamE & 6.7 \\
\hline A mixture of BrE and CamE & 36.7 \\
\hline American English (AmE) & 0 \\
\hline A mixture of AmE and CamE & 0 \\
\hline A native English other than BrE and AmE & 0 \\
\hline
\end{tabular}

The most striking observation about the data displayed in the above table is the fact that the percentage of those who claimed to speak British English (BrE) is as high as $33.3 \%$, in spite of the obvious Cameroonianisms that characterized every aspect of their speech. The fact that the informants claimed to speak BrE and, yet, displayed many aspects of CamE phonological features is quite significant. The declaration that they speak BrE shows their wish to comply with government's policy to promote SBE in Cameroon. The fact that there were noticeable Cameroonianisms in their speech suggests that CamE is still the unavoidable companion of those who strive to promote SBE in Cameroon, as shall be in the next section. Bamgbose (1984:171) reported a very similar situation involving an important personality in Nigeria who was very much against the idea of carrying out research on Nigerian English. The man strongly advocated the teaching of BrE and argued that there is no such thing as Nigerian English, thereby claiming that his own English is a reflection of BrE. A few minutes later, after an interruption from his audience, he said "let me land", instead of BrE "let me finish". The man is, in fact, a good speaker of typical Nigerian English and has a shallower knowledge of BrE than what he thought (Bamgbose, 1982:99ff).

The table also shows that as high as $36.7 \%$ of the informants reported that their speech was a mixture of both BrE and CamE. These informants can be said to be caught up between government's policy and the love for their local variety of English. Their profession as English Language teachers imposes some professional pressure on them to promote what the government policy prescribes, but at the same time they find it difficult to separate themselves from CamE, the variety of English that reflects their contextual realities.

\section{ON THE SUCCESS OR FAILURE OF PROMOTING SBE ACCENT IN CAMEROON}


Have pedagogic efforts significantly implanted SBE in Cameroon? We shall evaluate the SBE accent of teachers of English and journalists (those who are tacitly or officially expected to promote the so-called good English in Cameroon) and that of learners.

\section{A. Assessing the SBE Pronunciation of Teachers of English}

In a previous investigation (see Ngefac 2008a), 15 English language teachers were asked to articulate certain linguistic items according to the norms of SBE. Interestingly, the SBE pronunciation of a substantial number of these linguistic items was discovered to be completely lacking in the speech of the informants, as shown in the following table.

TABLE 2

PERCENTAGE OF SBE AND CAME PRONUNCIATION OF SOME LEXICAL ITEMS

\begin{tabular}{|c|c|c|c|c|c|c|}
\hline Words & $\begin{array}{l}\text { SBE } \\
\text { Pronunciation }\end{array}$ & $\begin{array}{l}\text { CamE } \\
\text { Pronunciation }\end{array}$ & $\begin{array}{l}\text { Frequency } \\
\text { of SBE }\end{array}$ & Frequency of CamE & $\%$ of SBE & $\%$ of CamE \\
\hline \multirow[t]{2}{*}{ commented } & 'commented & & 0 & & 0 & \\
\hline & & com'mented & & 15 & & 100 \\
\hline \multirow[t]{2}{*}{ insurance } & in'surance & & 0 & & 0 & \\
\hline & & 'insurance & & 15 & & 100 \\
\hline \multirow[t]{2}{*}{ preparatory } & pre'paratory & & 0 & & 0 & \\
\hline & & prepa'ratory & & 15 & & 100 \\
\hline \multirow[t]{2}{*}{ Explana-tory } & ex'planatory & & 0 & & 0 & \\
\hline & & expla'natory & & 15 & & 100 \\
\hline
\end{tabular}

(Adapted from Ngefac, 2008: 106)

In 2003 when I went to the field to assess student teachers involved in practice teaching, one of them was heard drilling his learners on the SBE stress pattern of the word "semester". He rightly explained that the word is stressed on the penultimate syllable in SBE, but the model pronunciation he was providing to his learners clearly showed that he was stressing the word on the first syllable as "semester", the CamE pronunciation of the word, instead of SBE se'mester.

A further evidence to prove that SBE is a far-fetched phenomenon to teachers of English in Cameroon is presented in Bobda (1993:441). The author presents the reaction of an English teacher to a feature of RP as follows:

A recent reaction of an old English teacher to the observation of a lecturer that "consumption" has /s/ instead of /z/ was: "what language is that?"

He goes further to state the reaction of a televiewer to a television programme "English With A Difference" on good English that presented the word "colonel" and kernel" as homophones. The televiewer is said to have argued and maintained that

If it is true that the author of EWAD [English With A Difference] admits that "colonel" (an army officer) and "kernel" (a nut) are pronounced the same, then it is unfortunate and the programme should be scraped before it does more harm (Bobda 1993:441, quoting Cameroon Tribune, No. 1936, August 1, 1989:15)

The first quotation above shows that English Language teachers who are presumed to be promoters of SBE accent are not even familiar with the SBE or RP variant. The question "what language is that?" is a clear exhibit that the teacher himself or herself, like the learners, is used only to the CamE variant which contains /z/, and not /s/ as in SBE.

The second quotation shows the reaction of another person who was probably not a teacher of English, but who, like the teacher of English, has a keen interest in English language issues. If such a person should dispute the fact that "colonel" and "kernel" are pronounced the same in SBE, it is an indication that this variety of English has so far not penetrated the hearts and minds of Cameroonians in general and English Language teachers in particular. This further shows that government's efforts to implant SBE accent in a New English setting with unique contextual realities is likely to yield very little fruits.

\section{B. Assessing the SBE Accent of Journalists}

As concerns journalists, there is sufficient evidence to justify the claim that SBE accent is significantly lacking in their speech, as a result of the contextual realities of Cameroon. In Ngefac (2008a) the speech of some categories of speakers, including journalists, was thoroughly studied. Like the case of English Language teachers previously discussed, none of the journalists assessed was able to realize the SBE pronunciation of the underlined portions of the words "cupboard", "of", "period", "village", "happy" and the SBE stress pattern of the words "commented", "insurance", illogical", preparatory", "explanatory", "authoritative" and "jubilee". Such results clearly show that SBE accent in Cameroon is a hidden phenomenon, even to journalists.

Another evidence is the fact that a substantial number of dissertations and theses have been written by students of the Departments of English at various universities in Cameroon on the English language production of journalists and the unanimous conclusion in most of these research works is that they significantly deviate from SBE accent. In spite of this general conclusion, there are noticeable features of British and American English phonological features in the speech of a handful of them, especially those who have spent some time in the UK and in the US.

\section{Assessing the SBE Accent of Learners of English in Cameroon}


Like the cases of English teachers and journalists, SBE remains a far-fetched phenomenon to learners of English, in spite of the assumption that this variety of English is being promoted in Cameroon. The difficulties Cameroonian learners of English face vis-à-vis SBE are presented in Talom (1990). He read out a number of words according to the norms of SBE to Upper Sixth students and they were asked to write down what they heard. The word "mayor" was rightly recognized by only $9 \%$ of his informants; as high as $78 \%$ wrote the word "man"; and as high as $13 \%$ could not write down anything because of the inaccessibility of the pronunciation to them. The word "climbing" was rightly recognized by only $30 \%$ of the informants; as high as $52 \%$ wrote down the word "climate"; $4 \%$ wrote down "time" and $13 \%$ failed to write down anything. As concerns the word "pestle", only $6 \%$ rightly recognized the word; as high as $26 \%$ thought the word read was "pencil", $37 \%$ wrote down the word "parcel"; $11 \%$ wrote down "person" and another $11 \%$ failed to make any attempt.

A situation very similar to the one reported by Talom (1990) was witnessed during one of my lectures at the Department of English at the University of Yaounde 1. Out of 108 students present in a Second Year Spoken English class, only $3.7 \%$ of the students were able to recognize the word "forehead", which was given a SBE rendition. The intelligibility rate was alarmingly low because such a pronunciation contrasts sharply with the CamE pronunciation of the word.

\section{CONCLUSION: SOCIOLINGUISTIC AND PEDAGOGIC IMPLICATIONS}

The evidence provided so far in this paper clearly shows that teachers, journalists and learners of English have little knowledge of SBE accent or RP, the pronunciation model targeted in the ELT industry in Cameroon. The sociolinguistic and pedagogic implications of such a situation are manifold. First, the conspicuous absence of many SBE phonological features and the dominance of typical CamE aspects in the speech of the speakers is an indication that CamE, which is the unavoidable companion of many Cameroonians, should be standardized and promoted in Cameroon. In this case, only uneducated CamE features should be discouraged. The educated aspects of CamE can be conveniently promoted on the Cameroonian landscape and the promotion of SBE and any other native variety of English (e.g. American English) should not constitute the main target in ELT in Cameroon.

Second, the scarcity of SBE pronunciation features in the speech of both teachers and learners shows that the necessary human and material resources to ensure the effective teaching of this variety of English are lacking, if at all the teaching of the variety is necessary. How many language or linguistic departments in secondary schools and universities in Cameroon have language laboratories for the effective teaching of the language? In some institutions, it is conspicuously inscribed "language laboratory" on certain doors, yet there is no single instrument in these rooms which has been preserved for the effective teaching of the language. How many British and American speakers of English have been recruited to teach SBE accent in Cameroon? How many teachers and journalists have been sponsored by the Cameroon government to travel to Britain for exposure to this model of pronunciation? It can therefore be recommended that instead of fruitlessly spending time and energy promoting SBE accent in Cameroon, the resources can be invested on the codification, standardization and promotion of educated CamE.

Third, the promotion of SBE at the expense of CamE is an indication that decision makers on language issues in Cameroon are not conversant with the new status that has, in recent years, been attributed to varieties of English spoken in the new nations. Instead of perceiving such varieties of English as error systems, inadequate learning, failures, incongruous concoctions, different scholars from different corners of the globe have successfully projected these Englishes as strong forces to reckon with. In fact, it has been unambiguously acknowledged that English in the Outer Circle, such as Cameroon, has developed through an itinerary that is conditioned by the sociolinguistic and cultural realities of the place and it is actually serving the communicative needs of the people concerned. I therefore suggest that decision makers on language issues in Cameroon should open their ears to current debates provided in international conferences in favor of the New Englishes and should also open their eyes to interesting argumentative essays published in international journals which x-ray the New Englishes as self-contained systems of communication, instead of spending their time castigating CamE and setting ELT goals in terms of Western standards.

\section{REFERENCES}

[1] Anchimbe, A. Eric. (2005). The World Englishes in the American Tongue. PHiN 32, 1-11.

[2] Anchimbe, A. Eric. (2006). Cameroon English: Authenticity, Ecology and Evolution. Frankfurt am Main: Peter Lang.

[3] Bamgbose, Ayo. (1971). The English Language in Nigeria. In Spencer, J. (ed.) The English Language in West Africa. London: Longman, 35-48.

[4] Bobda, Augustin Simo. (1991). Does Pronunciation Matter. English Teaching Forum 29 (4), 28 - 30.

[5] Bobda, Augustin Simo. (1993). English Pronunciation in Cameroon: Conflicts and Consequences. Journal of Multilingual and Multicultural Development, 14:6, 435-445.

[6] Bobda, Augustin Simo. (1994). Aspects of Cameroon English Phonology. Bern: Peter Lang.

[7] Bobda, Augustin Simo (2002). Watch Your English! (2nd ed.). Yaounde: B\&K.

[8] Crystal, David. (1997). A Dictionary of Linguistics and Phonetics. $4^{\text {th }}$ ed. Oxford: Blackwell Publishing Ltd.

[9] Graddol, D. (1997). The Future of English. UK: The British Council.

[10] Jenkins, Jennifer. (2000). The Phonology of English as an International Language. Oxford: Oxford University Press. 
[11] Kachru, B. Braj. (1985). Institutionalized Second-Language Varieties. In Greenbaum, S. (ed) (1985). The English Language Today, 221-226, Oxford: Pergamon Press, 221 - 226.

[12] Kachru, B. Braj (1986). The Alchemy of English. The Spread, Functions and Models of Non-native Englishes. Oxford: Pergamon Press.

[13] Kachru, B. Braj. (1992). World Englishes: Approaches, Issues and Resources”. Language Teaching, 25 (1), 1-14.

[14] Kouega, J. P. (1991). Some Speech Characteristics of Cameroon Media News in English. An Explanatory Study of Radio and Television News Text. Unpublished Doctorate de $3^{\mathrm{e}}$ Cycle thesis, University of Yaounde I.

[15] Kachru, B. Braj. (2003a). Camfranglais: a novel slang in Cameroon schools. English Today 19(2), 23-29.

[16] Kachru, B. Braj. (2003b). Word Formative Processes in Camfranglais. In World Englishes, 22 (4), 511-538.

[17] Masanga, D. W. (1983). The Spoken English of Educated Moghamo People: A phonological study. Unpublished Doctorate de $3^{\mathrm{e}}$ Cycle thesis. University of Yaounde I.

[18] Mazrui, Alamin M. and Mazrui, Ali A. (1996). A Tale of Two Englishes: The Imperial Language in Post-Colonial Kenya and Uganda. In Post-Imperial English, 271-302.

[19] Mbangwana, P. (1987). Some Characteristics of Sound Patterns of Cameroon Standard English. Multilingual, vol. 4, 411-424.

[20] Mbassi-Manga, F. (1973). English in Cameroon. A Study of Historical Contacts, Patterns of Usage and Current Trends. Unpublished $\mathrm{PhD}$ thesis, University of Yaounde.

[21] McArthur, T. (1998). The English Languages. Cambridge: CUP.

[22] Modiano, Marko. (1999a). International English in the Global Village. English Today, 15 (2), 22-28.

[23] Modiano, Marko. (1999b). Standard English(es) and Educational Practices for the World's Lingua Franca. English Today, 15 (4), 3-13.

[24] Mufwene, Salikoko S. (2001). The Ecology of Language Evolution. Cambridge: CUP.

[25] Mufwene, Salikoko. (1994). New Englishes and the criteria for naming them. World Englishes, 13, 21-31.

[26] Mufwene, Salikoko. (1997). Native Speaker, Proficient Speaker, and Norm. Native speaker: multilingual perspectives. Edited by Rajendra Singh. New Delhi: Sage Publication, 111-123.

[27] Ngefac, Aloysius .(2009). Which English for Cameroonians in the new millennium: the quest for English and cultural identity. Annals, FALSS, University of Yaounde I.

[28] Ngefac, Aloysius. (2008a). Social Differentiation in Cameroon English: Evidence from Sociolinguistic Fieldwork. New York: Peter Lang.

[29] Ngefac, Aloysius. (2008b). The Social Stratification of English in Cameroon. World Englishes, 27, (3/4), 407-418.

[30] Ngefac, Aloysius. (2005). Homophones and Heterophones in Cameroon English. Alizes, 25/26, 39-53.

[31] Ngefac, Aloysius. (2006a). Linguistic variants as signals of social hierarchy: The ambiguous situation of Cameroon. PHiN 35 , 25-32.

[32] Ngefac, Aloysius and Bonaventure M. Sala. (2006b). Cameroon Pidgin and Cameroon English at a confluence: A real-time investigation. English World-Wide, 27 (2), 217-227.

[33] Ngefac, Aloysius and Bonaventure M. Sala. (2006c). What's happening to Cameroon Pidgin English? The depidginisation of Cameroon Pidgin English. PhiN 36.

[34] Passé, H. A. (1947). The English Language in Ceylon. Unpublished Doctoral Dissertation, University of London.

[35] Platt, John, Heidi Weber and Ho Mian Lian. (1984). The New Englishes. London: Routlege and Kegan Paul.

[36] Rajadurai, Joanne. (2005). Revisiting the Cconcentric Circles: Conceptual and Sociolinguistic Considerations. Asian EFL Journal, 7 (4), 1-24.

[37] Schmied, Josef. (1991). English in Africa. New York: Longman.

[38] Sey, Kofi A. (1973). Ghanaian English. London: Macmillan.

[39] Talom, P. (1992). The intelligibility of some RP forms in Cameroon. Unpublished postgraduate dissertation, ENS Yaounde, University of Yaounde I.

[40] Todd, Loreto. (1999). Global English. English Today, 15 (2), 30-31.

[41] Todd, Loreto. (1991). Talk Pidgin. A Structured Course in West African Pidgin English. Leeds: Tortoise Books.

\footnotetext{
Aloysius Ngefac holds a PhD and many other academic and professional certificates from the University of Yaounde 1, Cameroon, where he is currently Senior Lecturer at the Advanced College of Education. He has won international awards such as the Alexander von Humboldt Fellowship for Experienced Researchers, the Fulbright Senior Scholarship and the DAAD and has given guest lectures in such universities as the University of Pennsylvania, City University of New York, Indiana State University, Indiana University and Drexel University. He is author of Social Differentiation in Cameroon English (New York: Peter Lang, 2008) and many scholarly papers, which have appeared in journals such as World Englishes and English World-Wide.
} 